\title{
Violence, burnout and minor psychiatric disorders in hospital work ${ }^{*}$
}

\author{
Violência, burnout e transtornos psíquicos menores no trabalho hospitalar \\ Violencia, burnout y trastornos psíquicos menores en el trabajo hospitalario
}

Daiane Dal Pai ${ }^{1}$, Liana Lautert² ${ }^{2}$ Sônia Beatriz Cocaro de Souza ${ }^{3}$, Maria Helena Palucci Marziale ${ }^{4}$, Juliana Petri Tavares ${ }^{5}$

* Extracted from the thesis "Violência no Trabalho em Pronto Socorro: implicações para a saúde mental dos trabalhadores," Post-graduation Program in Nursing, Universidade Federal do Rio Grande do Sul, 2011.

${ }^{1}$ Adjunct Professor, Department of Medical Surgery Nursing, Universidade Federal do Rio Grande do Sul, Porto Alegre, RS, Brazil.

${ }^{2}$ Tenured Professor, Department of Medical Surgery Nursing, Universidade Federal do Rio Grande do Sul, Porto Alegre, RS, Brazil.

${ }^{3}$ Associate Professor, Department of Medical Surgery Nursing, Universidade Federal do Rio Grande do Sul, Porto Alegre, RS, Brazil.

${ }^{4}$ Tenured Professor, Department of General and Specialized Nursing, Ribeirão Preto School of Nursing, Universidade de São Paulo, Ribeirão Preto, SP, Brazil.

${ }^{5}$ Professor, Nursing Program, Centro

Universitário Metodista IPA, Porto Alegre, RS, Brazil.

\section{ABSTRACT}

Objective: Identifying the violence suffered by the health team workers and their association with Burnout and minor psychiatric disorders. Methods: Cross-sectional study with 269 health team professionals of a public hospital in southern Brazil. Data were collected through the use of the Survey Questionnaire: Workplace Violence in the Health Sector, Maslach Inventory Burnout and Self-Report Questionnaire. Results: Workplace violence struck $63.2 \%$ of workers, prevailing mostly in women $(p=0.001)$, among nursing auxiliaries/technicians $(\mathrm{p}=0.014)$ and was associated with minor psychiatric disorders $(p<0.05)$, as exposure to different forms of violence increased the chances of these disorders by $60 \%$ (CI 95\%:1.2-2.1). The three Burnout dimensions were also associated to violence at work $(\mathrm{p}<0.05)$. Conclusion: Health workers experience violence in the workplace and this exposure is associated with Burnout symptoms and minor psychiatric disorders.

\section{DESCRIPTORS}

Workplace Violence; Occupational Health; Health Manpower; Nursing Staff. 


\section{INTRODUCTION}

Workplace violence is considered a growing phenomenon in the world and a major public health problem, and has been appointed by the health sector as a prevalent field for the occurrence of attacks on workers ${ }^{(1-2)}$. Therefore, violence at work has gained international prominence in discussions on the challenges related to human resources for health ${ }^{(3-5)}$. Prevalence rates show that the problem of violence in health services range from 17 to $94 \%$, and frequently exceeds $50 \%$ of workers ${ }^{(2-6)}$.

The potential for this exposure can be attributed to the characteristics of performed activities by health professionals, which involves constant physical contact and intense interaction with people who receive their care, as well as their families and caregivers ${ }^{(3,6)}$. Still, the unfavorable conditions for the provision of care can be understood as disagreements which generate barriers that can easily evolve into assaults between patients and health professionals, or among the professionals themselves, since both have infringed on their expectations and desires ${ }^{(7-8)}$. In this context, it is understood that workplace violence is in the form of aggression stemming from labor relations and is presented in the form of threats, abuse or attacks ${ }^{(1)}$, having its origins directly related to the conditions and organization of work.

In the international scenario, studies have revealed concern about violence in health services ${ }^{(2,5-6)}$. However, in Brazil the problem still needs to be studied further ${ }^{(8-10)}$, since the invisibility of its occurrence and consequences contributing to the attacks are treated as "natural" in many work environments and the magnitude of the problem is underestimated.

The negative consequences of violence on the health of workers and the assistance provided have been evidenced by symptoms of stress, low self-esteem and the demotivation of the victims ${ }^{(5,10-12)}$. These symptoms, which have been linked to the exposure of workers to violence and are characteristic of Burnout, a prevalent syndrome in health workers and characterized by high levels of emotional exhaustion, depersonalization, and low job satisfaction ${ }^{(13)}$.

In addition, minor psychiatric disorders have also been linked to the victims of violence at work $^{(9)}$, which are described as non-psychotic psychiatric symptoms ${ }^{(14)}$, such as anxiety, insomnia, sadness, fatigue, forgetfulness, difficulty in concentrating, irritability, somatic complaints and neurasthenia. Thus, in addition to the interest in identifying the violence suffered by workers of the health team, this study questioned its association with Burnout and minor psychiatric disorders. Given the above, the objective was to identify the violence suffered by the health team workers and its association with Burnout and minor psychiatric disorders.

\section{METHOD}

This is a cross-sectional study in a public referral hospital for trauma care in southern Brazil. This service has 139 beds and provides more than 900 daily visits, starting at emergency rooms with inpatient units, surgery and intensive care. The professionals work in the position of effective provision and are governed by municipal statute.

The study sample consisted of 269 subjects, defined according to sample calculation on the population of 1,025 health team professionals. The sample size calculation was performed with the aid of software WinPepi version 9.4, assuming a confidence level of $95 \%, 5 \%$ error estimate, $80 \%$ power and prevalence of $50 \%$.

The random selection of subjects was performed by a draw, stratified according to the proportion of professional categories over the whole of 349 doctors, 103 nurses, 482 nursing auxiliaries/technicians and 91 professionals from other health team categories (social workers, psychologists, physiotherapists, dentists, nutritionists and radiology technicians), regardless of shift or sector. We selected the subjects from a list of employees provided by the hospital's human resources sector, and we set a year of service in the hospital as the minimum time for inclusion criteria and that they had to be active in the period of data collection, which occurred during the months of June-August 2011. In the case where someone refused to participate in the study $(n=7)$, they were replaced by people from within the same category and following the same type of draw.

For the data collection, participants answered questions that verified demographic and labor information. To evaluate the occurrence of violence in the last 12 months, we used the Survey Questionnaire Workplace Violence in the Health Sector ${ }^{(15)}$, proposed by the World Health Organization, International Labour and Public Services Organization, and International Council of Nurses, and it was translated and adapted to Portuguese ${ }^{(16)}$. For professionals who also worked at other institutions, the focus of the research was clarified as the episodes of violence that only occurred at this study site.

Burnout was assessed by the Maslach Burnout Inventory $(\mathrm{MBI})^{(17)}$, which detects a syndrome characterized by high emotional exhaustion, depersonalization, and low professional efficacy. These dimensions make up the scale of 22 questions used to identify Burnout. The MBI was translated into Portuguese and validated in Brazil, with a Cronbach's alpha of 0.86 in the subscale of emotional exhaustion, 0.69 for depersonalization and 0.76 in professional efficacy ${ }^{(13)}$.

To track Minor Psychiatric Disorders, we used the SelfReport Questionnaire (SRQ-20) recommended by the World Health Organization and validated for the Brazilian population in 1986 with $83 \%$ sensitivity and $80 \%$ specificity $^{(14)}$. The SRQ has 20 questions that assess non-psychotic psychiatric symptoms.

We coded and tabulated data with the aid of Microsoft Windows Excel, and performed statistical analysis using the Statistical Package for Social Sciences software (SPSS), version 18.0. For sociodemographic and labor variables, we calculated relative and absolute frequencies when categorical, and measures of central tendency and dispersion when continuous. The factor studied (workplace violence) was analyzed with dichotomous categories (victims and non-victims of violence) and considered being exposed to different forms 
of perpetration of physical, verbal, moral, racial and/or sexual violence as a continuous variable.

We treated the SRQ-20 scores and MBI dimensions as scalar variables, obtaining a mean and standard deviation. The cutoff point in the SRQ-20 scale was seven positive responses for both genders, thereby constituting the groups with and without Minor Psychiatric Disorders ${ }^{(14)}$. To identify levels (high, moderate and low) of Burnout dimensions, we selected the higher or equal scores to the 75 th percentile on the subscales of emotional exhaustion and depersonalization, and up to 25 th percentile in the professional efficacy subscale. The categorical variable of Burnout (yes or no) was observed in subjects with high emotional exhaustion and depersonalization, and low professional efficacy ${ }^{(13)}$.

We found associations between the groups using the chi-square test. The differences between mean scores of MBI and SRQ-20 were then analyzed using the $t$-test (for variables with normal distribution) and Mann-Whitney test (for variables with asymmetric distribution). The correlations with exposure to different forms of violence were carried out using Spearman and Kruskal-Wallis tests.

In multiple logistic regression analysis, the influence of independent variables on the outcomes (Burnout and Minor Psychiatric Disorders) were verified first, in order to select variables with $\mathrm{p}<0.15$ to be included in the analytical model. We considered the results statistically significant if $\mathrm{p} \leq 0.05$ values in Poisson multiple regression analyzes (Minor Psychiatric Disorders) and multiple linear regression (Burnout dimensions).

The study met the ethical prerequisites of research involving human beings, according to Resolution 196 of 1996 of the National Health Council and was approved by the Research Ethics Committee, under number 001.014667.11.8. All subjects signed a two-way Consent Form.

\section{RESULTS}

The study was conducted with 269 health workers, of which 157 (58.4\%) were female, with an average of 49 $(+7.4)$ years of age, who had companions $(63.9 \%, \mathrm{n}=172)$, median of two (1-2) children, education median of 17 (1421) years of education, average professional experience of $24.8(+7.8)$ years of experience in health and $16.2(+7.7)$ years at the institution.

Regarding the professional category, the sample consisted of 122 (45.4\%) nursing auxiliaries/technicians, 27 (10\%) nurses, $90(33.5 \%)$ physicians and $30(11.1 \%)$ other health professionals. Most worked in critical care units $(44.2 \%, \mathrm{n}$ = 119), such as intensive care units and an operating room, followed by emergency rooms $(21.9 \%, \mathrm{n}=59)$, inpatient units $(17.8 \%, \mathrm{n}=48)$ and other sectors $(16 \%, \mathrm{n}=43)$, which included the blood bank units, radiology, physiotherapy, psychology and social work.

Sample distribution into work shifts revealed that $39.4 \%$ ( $\mathrm{n}=106$ ) of participants worked during the day and $27.9 \%$ ( $\mathrm{n}=75$ ) at night. Long shifts (with periods including day and night) were reported by $32.7 \%(\mathrm{n}=88)$ of the sample. The weekly workload of workers had a median of 40 (3040) hours per week. Most subjects $(63.2 \%, \mathrm{n}=170)$ reported not working at other institutions and $8.9 \%(n=24)$ of the workers had some kind of leading responsibility.

In the sample, $63.2 \%(n=170)$ of the subjects were exposed to violence, with a prevalence of female victims ( $\mathrm{p}$ $=0.001)$, younger $(\mathrm{p}=0.044)$, lower education $(\mathrm{p}=0.036)$ and belonging to the professional category of nursing auxiliaries/technicians $(\mathrm{p}=0.014)$ (Table 1$)$. Among the victims, we found that $35 \%(n=94)$ experienced one type of violence, while $28.2 \%$ ( $\mathrm{n}=76$ ) of the sample had been exposed to two or more forms of violence perpetrated at work.

Table 1 - Distribution of workers exposed and not exposed to violence at work, according to sociodemographic and labor characteristics - Porto Alegre, RS, Brazil, 2011.

\begin{tabular}{|c|c|c|c|}
\hline \multirow[b]{2}{*}{ Sociodemographic and Labor Variables } & \multicolumn{2}{|c|}{ Workplace Violence } & \multirow[t]{2}{*}{$\mathbf{P}$} \\
\hline & $\begin{array}{c}\text { Yes } \\
(\mathrm{n}=170)\end{array}$ & $\begin{array}{c}\text { No } \\
(\mathbf{n}=99)\end{array}$ & \\
\hline $\begin{array}{c}\text { Gender }^{*} \\
\text { Female } \\
\text { Male }\end{array}$ & $\begin{array}{c}112(71.3) \\
58(51.8)\end{array}$ & $\begin{array}{l}45(28.7) \\
54(48.2)\end{array}$ & $0.001^{\mathrm{s}}$ \\
\hline $\mathrm{Age}^{+}$ & $48.5( \pm 6.9)$ & $49.8( \pm 8.2)$ & $0.044 \|$ \\
\hline 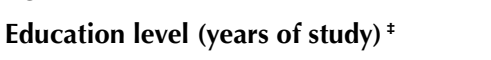 & $17(14-20)$ & $18(14-23)$ & $0.036^{\prime}$ \\
\hline Average hours of sleep ${ }^{+}$ & $6.4( \pm 1.4)$ & $6.6( \pm 1.1)$ & $0.373^{\|}$ \\
\hline $\begin{array}{c}\text { Smokers* }^{*} \\
\text { Yes } \\
\text { No }\end{array}$ & $\begin{array}{c}22(68.7) \\
148(62.4)\end{array}$ & $\begin{array}{l}10(31.3) \\
89(37.6)\end{array}$ & $0.488^{\S}$ \\
\hline Experience time in healthcare $^{\dagger}$ & $24.6( \pm 7.4)$ & $25.2( \pm 8.5)$ & $0.331^{\|}$ \\
\hline Experience time at the institution ${ }^{+}$ & $15.9( \pm 6.9)$ & $16.6( \pm 8.9)$ & $0.275^{\|}$ \\
\hline $\begin{array}{l}\text { Work sector } \\
\text { Emergency rooms } \\
\text { Critical Units } \\
\text { Inpatient units } \\
\text { Other }\end{array}$ & $\begin{array}{l}43(72.9) \\
67(56.3) \\
34(70.8) \\
26(60.5)\end{array}$ & $\begin{array}{l}16(27.1) \\
52(43.7) \\
14(29.2) \\
17(39.5)\end{array}$ & $0.104^{\S}$ \\
\hline $\begin{array}{l}\text { Professional category }{ }^{*} \\
\text { Nursing auxiliaries /technicians } \\
\text { Nurse } \\
\text { Doctor } \\
\text { Others }\end{array}$ & $\begin{array}{l}88(72.1) \\
19(70.4) \\
47(52.2) \\
16(53.3)\end{array}$ & $\begin{array}{c}34(27.9) \\
8(29.6) \\
43(47.8) \\
14(46.7)\end{array}$ & $0.014^{\S}$ \\
\hline
\end{tabular}




\begin{tabular}{|c|c|c|c|}
\hline \multirow[b]{2}{*}{ Sociodemographic and Labor Variables } & \multicolumn{2}{|c|}{ Workplace Violence } & \multirow[t]{2}{*}{$\mathbf{P}$} \\
\hline & $\begin{array}{c}\text { Yes } \\
(n=170)\end{array}$ & $\begin{array}{c}\text { No } \\
(n=99)\end{array}$ & \\
\hline $\begin{array}{l}\text { Work shift* } \\
\text { Day time } \\
\text { Night time } \\
\text { On shift }\end{array}$ & $\begin{array}{l}70(66.0) \\
52(69.3) \\
48(54.5)\end{array}$ & $\begin{array}{l}36(34.0) \\
23(30.7) \\
40(45.5)\end{array}$ & $0.110^{\S}$ \\
\hline Week workload ${ }^{\ddagger}$ & $40(30-40)$ & $36(30-40)$ & $0.012^{9}$ \\
\hline $\begin{array}{l}\text { Working at another institution* } \\
\text { Yes } \\
\text { No }\end{array}$ & $\begin{array}{c}57(57.6) \\
113(66.5)\end{array}$ & $\begin{array}{l}42(42.4) \\
57(33.5)\end{array}$ & $0.145^{\S}$ \\
\hline $\begin{array}{l}\text { Work accidents } \\
\text { Yes } \\
\text { No }\end{array}$ & $\begin{array}{l}96(69.1) \\
74(56.9)\end{array}$ & $\begin{array}{l}43(30.9) \\
56(43.1)\end{array}$ & $0.009^{\ddagger}$ \\
\hline$N^{o}$ of Accidents ${ }^{\dagger}$ & $1(0-2)$ & $0(0-1)$ & $0.045^{\S}$ \\
\hline Days missed from work last year ${ }^{\dagger}$ & $0(0-10)$ & $0(0-3)$ & $0.018^{\S}$ \\
\hline $\begin{array}{l}\text { Satisfied with their work } \\
\text { Yes } \\
\text { No }\end{array}$ & $\begin{array}{l}92(58.2) \\
78(71.6)\end{array}$ & $\begin{array}{l}66(41.8) \\
31(28.4)\end{array}$ & $0.026^{\ddagger}$ \\
\hline Interpersonal relationships review ${ }^{\dagger}$ & $4(4-4)$ & $4(4-4)$ & $0.058^{\S}$ \\
\hline $\begin{array}{l}\text { Job recognition* } \\
\text { Yes } \\
\text { No }\end{array}$ & $\begin{array}{l}82(54.3) \\
87(74.4)\end{array}$ & $\begin{array}{l}69(45.7) \\
30(25.6)\end{array}$ & $0.001^{\ddagger}$ \\
\hline Concern about violence $^{+}$ & $4(3-5)$ & $2(1-3)$ & $<0.001^{\text {s }}$ \\
\hline
\end{tabular}

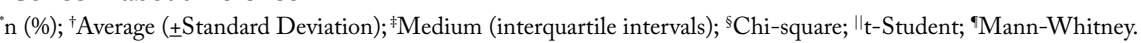

Note: Work accidents included typical accidents, the most reported were biological and ergonomic accidents, human aggressions were not included in this variable. Interpersonal relationships review was assessed on a 5 point scale: (1) very bad; (2) bad; (3) regular; (4) good; (5) great. Concern about violence was assessed on a 5 point scale: (1) not worried; (2) slightly worried; (3) moderate concern; (4) concerned; (5) very concerned

We identified 46 (17.1\%) workers with Minor Psychiatric Disorders (MPD), of which 38 (82.6\%) reported exposure to violence $(\mathrm{p}=0.003)$ (Table 2$)$.

In the same table significant correlation between MPD and exposure to multiple forms of violence can be seen. From the selection of labor and sociodemographic variables associated with MPD, the strength of association was analyzed using Poisson regression model (Table 3).

From the prevalence ratio, it was possible to establish that exposure to different forms of perpetrated violence compounded the chances of these disorders by $60 \%$ (95\% CI: 1.2-2.1).

Table 2 - Distribution of workers according to the presence of Minor Psychiatric Disorders and scores of the SRQ-20 according to total sample, victims of violence and exposure to different forms of violence suffered at work - Porto Alegre, RS, Brazil, 2011.

\begin{tabular}{|c|c|c|c|c|c|c|}
\hline & \multirow{2}{*}{$\begin{array}{c}\text { Total sample } \\
(\mathrm{n}=269)\end{array}$} & \multicolumn{2}{|c|}{ Violence } & \multirow[b]{2}{*}{$\mathbf{p}$} & \multirow{2}{*}{$\begin{array}{l}\text { Different forms of } \\
\text { violence } \\
(\mathbf{n}=269)\end{array}$} & \multirow[b]{2}{*}{$\mathbf{P}$} \\
\hline & & $\begin{array}{c}\text { Yes } \\
(n=170)\end{array}$ & $\begin{array}{c}\text { No } \\
(n=99)\end{array}$ & & & \\
\hline $\begin{array}{l}\text { MPD }^{*+} \\
\text { Yes } \\
\text { No }\end{array}$ & $\begin{array}{c}46(17.1) \\
223(82.9)\end{array}$ & $\begin{array}{c}38(82.6) \\
132(59.2)\end{array}$ & $\begin{array}{c}8(17.4) \\
91(40.8)\end{array}$ & $0.003^{\S}$ & $\begin{array}{l}2(1-2) \\
1(0-1)\end{array}$ & $<0.001$ \\
\hline MPD scores ${ }^{\ddagger}$ & $2(1-5)$ & $3(1-6)$ & $2(0-4)$ & $<0.001$ |। & 0.330 & $<0.001^{9}$ \\
\hline
\end{tabular}

in (\%); ${ }^{\dagger}$ Medium (interquartile intervals); ${ }^{\ddagger}$ Correlation coefficient; ${ }^{\S} \mathrm{Chi}-$ square; $"$ Mann-Whitney. ${ }^{\top}$ Spearman.

Legend: MPD - Minor Psychiatric Disorders

Table 3 - Poisson Regression Model for variables associated with Minor Psychiatric Disorders - Porto Alegre, RS, Brazil, 2011.

\begin{tabular}{lcc}
\hline Variables & PR (95\% CI) & P \\
\hline $\mathbf{N}^{\mathbf{0}}$ of children & $0.7(0.5-0.9)$ & 0.016 \\
Years of experience in healthcare (every 5 years) & $1.3(1.1-1.6)$ & 0.015 \\
Professional Category & & \\
$\quad$ Nursing auxiliaries /technicians & $3.5(0.8-15.3)$ & 0.095 \\
$\quad$ Nurse & $2.5(0.4-13.8)$ & 0.303 \\
$\quad$ Doctor & $2.9(0.6-13.8)$ & 0.165 \\
$\quad \mathbf{N}^{\mathbf{0}}$ of professionals present & 1.0 & 0.064 \\
Satisfaction with work place & $1.0(0.9-1.1)$ & \\
$\quad$ Yes & & 0.032 \\
$\quad \mathbf{N}^{\mathbf{N}}$ of work Accidents & $0.6(0.3-0.9)$ & 1.0 \\
\hline
\end{tabular}




\begin{tabular}{lcc}
\hline ...continuation & & \\
\hline Variables & PR (95\% CI) & P \\
\hline Days missed from work & 1.0 & 0.205 \\
$\quad$ None & $1.6(0.8-3.4)$ & 0.087 \\
$\quad 1$ week & $1.8(0.9-3.4)$ & 0.004 \\
$\quad$ week to 2 months & $3.5(1.5-8.1)$ & 0.001 \\
Exposure to different forms of violence & $1.6(1.2-2.1)$ & \\
\hline
\end{tabular}

Legend: PR = Prevalence Ratio; CI = Confidence Interval.

The application of MBI confirmed Burnout in 18 (6.7\%) workers, among which 13 had experienced violence at work $(\mathrm{p}=0.411)$. The high levels of emotional exhaustion and depersonalization, and low professional efficacy were associ- ated with violence (Table 4).

Linear regression was conducted from the selection of demographic and labor variables associated with each of the dimensions that make up Burnout (Table 5).

Table 4 - Distribution of means and levels of Burnout dimensions and Burnout syndrome, according to the exposure of workers to violence and the different forms of violence. Porto Alegre, RS, Brazil, 2011.

\begin{tabular}{|c|c|c|c|c|c|c|}
\hline & \multirow{2}{*}{$\begin{array}{c}\text { Total } \\
(\mathbf{n}=\mathbf{2 6 9})\end{array}$} & \multicolumn{2}{|c|}{ Violence } & \multirow[b]{2}{*}{$\mathbf{p}$} & \multirow{2}{*}{$\begin{array}{l}\text { Different } \\
\text { forms of } \\
\text { violence } \\
(n=269)\end{array}$} & \multirow[b]{2}{*}{ p } \\
\hline & & $\begin{array}{c}\text { Yes } \\
(n=170)\end{array}$ & $\begin{array}{c}\text { No } \\
(n=99)\end{array}$ & & & \\
\hline $\begin{array}{l}\text { Burnout }^{*+} \\
\text { Yes } \\
\text { No }\end{array}$ & $\begin{array}{c}18(6.7) \\
251(93.3)\end{array}$ & $\begin{array}{c}13(72.2) \\
157(62.6)\end{array}$ & $\begin{array}{c}5(27.8) \\
94(37.4)\end{array}$ & $0.411^{\|}$ & $\begin{array}{l}1(0-2) \\
1(0-2)\end{array}$ & $0.196^{\circ}$ \\
\hline $\begin{array}{l}\text { Burnout Dimensions } \neq \$ \\
\text { Emotional exhaustion } \\
\text { Professional efficacy } \\
\text { Depersonalization }\end{array}$ & $\begin{array}{c}28.2( \pm 11.6) \\
47.2( \pm 7.1) \\
10.6( \pm 5.8)\end{array}$ & $\begin{array}{c}30.3( \pm 11.2) \\
46.7( \pm 6.8) \\
11.3( \pm 6.2)\end{array}$ & $\begin{array}{c}24.5( \pm 11.6) \\
48.1( \pm 7.5) \\
9.2( \pm 4.8)\end{array}$ & $\begin{array}{l}<0.001^{* *} \\
0.099^{* *} \\
0.002^{* *}\end{array}$ & $\begin{array}{c}0.322 \\
-0.150 \\
0.164\end{array}$ & $\begin{array}{c}<0.001^{++} \\
0.014^{++} \\
0.007^{++}\end{array}$ \\
\hline $\begin{array}{l}\text { Burnout Levels }{ }^{*+} \\
\text { Emotional exhaustion } \\
\text { Low } \\
\text { Moderate } \\
\text { High }\end{array}$ & $\begin{array}{c}68(25.3) \\
133(49.4) \\
68(25.3)\end{array}$ & $\begin{array}{l}32(47.1) \\
84(63.2) \\
54(79.4)\end{array}$ & $\begin{array}{l}36(52.9) \\
49(36.8) \\
14(20.6)\end{array}$ & $<0.001 \|$ & $\begin{array}{l}0(0-1) \\
1(0-2) \\
1(1-2)\end{array}$ & $<0.001^{\text {f }}$ \\
\hline $\begin{array}{l}\text { Professional efficacy } \\
\text { Low } \\
\text { Moderate } \\
\text { High }\end{array}$ & $\begin{array}{c}73(27.1) \\
122(45.4) \\
74(27.5)\end{array}$ & $\begin{array}{l}54(74.0) \\
78(63.9) \\
38(51.4)\end{array}$ & $\begin{array}{l}19(26.0) \\
44(36.1) \\
36(48.6)\end{array}$ & $0.017^{\|}$ & $\begin{array}{c}1(0-2) \\
1(0-1.3) \\
1(0-1)\end{array}$ & $0.011^{\neq \neq}$ \\
\hline $\begin{array}{l}\text { Depersonalization } \\
\text { Low } \\
\text { Moderate } \\
\text { High }\end{array}$ & $\begin{array}{c}78(29.0) \\
123(45.7) \\
68(25.3)\end{array}$ & $\begin{array}{l}46(59.0) \\
71(57.7) \\
53(77.9)\end{array}$ & $\begin{array}{l}32(41.0) \\
52(42.3) \\
15(22.1)\end{array}$ & $0.014 \|$ & $\begin{array}{l}1(0-2) \\
1(0-2) \\
1(1-2)\end{array}$ & $0.053^{\neq \neq}$ \\
\hline
\end{tabular}

Table 5 - Multiple linear regression model to the dimensions of Burnout - Porto Alegre, RS, Brazil, 2011.

\begin{tabular}{|c|c|c|c|c|}
\hline Dimensions & Variables & B & $\mathbf{p}$ & $\mathbf{r}^{2}$ \\
\hline \multirow[t]{7}{*}{ Emotional exhaustion } & White & -2.574 & 0.081 & 0.306 \\
\hline & Number of children & -0.961 & 0.055 & \\
\hline & Interpersonal relationships review & -1.513 & 0.084 & \\
\hline & Job satisfaction & -5.502 & $<0.001$ & \\
\hline & Recognition at work & -5.432 & $<0.001$ & \\
\hline & Concern about violence & 0.924 & 0.048 & \\
\hline & Different forms of violence & 2.019 & 0.003 & \\
\hline \multirow[t]{6}{*}{ Professional efficacy } & Age & 0.124 & 0.028 & 0.157 \\
\hline & Number of children & 0.763 & 0.029 & \\
\hline & $\begin{array}{l}\text { Professional Category } \\
\text { Nursing auxiliaries/technicians } \\
\text { Nurse } \\
\text { Doctor } \\
\text { Other }\end{array}$ & $\begin{array}{l}1.805 \\
1.154 \\
2.901\end{array}$ & $\begin{array}{l}0.193 \\
0.512 \\
0.043\end{array}$ & \\
\hline & Hours of sleep & -0.598 & 0.056 & \\
\hline & Interpersonal relationships review & 1.137 & 0.053 & \\
\hline & Job recognition & 3.388 & $<0.001$ & \\
\hline
\end{tabular}




\begin{tabular}{|c|c|c|c|c|}
\hline Dimensions & Variables & B & $\mathbf{p}$ & $\mathbf{r}^{2}$ \\
\hline \multirow[t]{8}{*}{ Depersonalization } & Number of children & -0.684 & 0.012 & 0.122 \\
\hline & $\begin{array}{l}\text { Work sector } \\
\text { Urgency or Emergency rooms }\end{array}$ & & & \\
\hline & Critical Units & -1.572 & 0.159 & \\
\hline & Inpatient units & -2.909 & 0.003 & \\
\hline & Other & -2.866 & 0.014 & \\
\hline & Working at another institution & 1.574 & 0.025 & \\
\hline & Job recognition & -2.054 & 0.003 & \\
\hline & Different forms of violence & 0.930 & 0.010 & \\
\hline
\end{tabular}

Legend: B - angular regression coefficient; $\mathrm{r}^{2}$ - determination coefficient.

On the variables of influence on the dimensions of Burnout, there is a correlation between increased exposure to different forms of perpetrated violence and Emotional Exhaustion ( $p=0.003)$, as for every increase in violence that the worker suffered, there was an average increase of two points in that dimension. Workplace violence remained in the final regression model of professional efficacy. Increased exposure to different forms of perpetrated violence at work was correlated with depersonalization $(\mathrm{p}=0.003)$.

\section{DISCUSSION}

The percentage of victims of violence at work (63.2\%) exceeds the statistical studies that used the same investigation strategy in the health services of Bahia ${ }^{(18)}$, of Rio de Janeiro (46.7\%) and in countries such as Portugal (37\%), Thailand (54\%) and South Africa (61\%)(15). However, it was lower than the prevalence in Australia (67.2\%) and Bulgaria $(75.8 \%)^{(15)}$.

In Australia, another study found that $52 \%$ of health professionals were victims of some form of violence at work in the last four weeks ${ }^{(4)}$. Similar findings were seen in a Swiss university hospital, with $50 \%$ of violence in the last 12 months and $11 \%$ in the last week ${ }^{(6)}$. These data reveal the prevalence of victims in a recent period, featuring workplace violence as a phenomenon occurring in labor every day. Brazilian studies have identified a prevalence of $25-65 \%$ for some kind of violence in the last 12 months $^{(9,18)}$.

The prevalence of the auxiliary/practical nurse category among the victims of violence in the study setting, as well as workers with less education was also predominant among the victims, reinforcing the higher exposure of nursing professionals with a medium level in this study. Brazilian studies have highlighted the exposure of these professionals ${ }^{(16,18)}$.

Some authors state that nursing is more exposed to violence from both the profile of their direct care activities to the patient ${ }^{(5-6,11)}$ and the predominance of female workers ${ }^{(5)}$, placing particular emphasis on the implications of gender being aggravating. A longitudinal study pointed to the exposure of nurses to gender violence, finding that in this class there was an increased risk of violence due to the overlap of labor abuse to domestic violence, and an increase in the chances of stress and depression ${ }^{(19)}$. The implication of gender on the understanding of violence should consider the historical cultural and economic inequality between genders, for which women have been in unfavorable conditions. Females having the largest distribution in the group of workers exposed to occupational violence has been recurrent in the health sector ${ }^{(5,9,12)}$.

Victims of violence at work in the past year had lower average age than those not exposed to violence in the last year, reinforcing findings of other studies ${ }^{(5,9,12,18,20-21)}$. This result can be explained from the perspective of young professionals who have less expertise in the development of their work activities and thus would have less ability to prevent attacks. However, the differences related to professional practice time do not reinforce this fact.

The exposure of health workers to violence at work has been linked to higher workloads in labor ${ }^{(12,20)}$, according to results of this study. In addition to concluding that the increase of the incidents stems from the increase in exposure time to the phenomenon, it is considering the possibility that overload is reflected in behaviors that add risk, such as less attention to detail or greater irritability. Other Brazilian studies ${ }^{(9,16)}$ describe the precariousness of employment contracts as an aspect that focuses on the vulnerability of workers.

The shift of the victims had no significant prevalence. These findings differ from other studies ${ }^{(5,12,16,20)}$, which indicated increased exposure for professionals who work at night.

Workplace violence may reflect on different aspects of working life; in this study we highlight the negative relationship on satisfaction and recognition at work. Other studies showed association to employee dissatisfaction ${ }^{(9-10)}$, demotivation to work ${ }^{(10)}$, decreased professional commitment $^{(5)}$, damage to teamwork, experiences working under pressure and physical overload ${ }^{(12)}$.

A study also found that violence interferes on adverse events in nursing care ${ }^{(22)}$. However, we found no studies to confirm the data from this research on the prevalence of occupational accidents among workers exposed to violence, but it is understood that accidents are representations of emotional and cognitive impairments brought about by the experience of violence. Workplace violence was associated with worker's absences, complementing findings in the literature that indicate this phenomenon as the cause of absence ${ }^{(3,9)}$. However, we note that in addition to the underreporting of violence in health services ${ }^{(8)}$, it has not been registered as cause of removal, which may result in the same occurring in health services.

Victims of workplace violence have been concerned about this issue ${ }^{(10,16)}$, which is linked to the discontent from 
their experiences and to consequences of worker safety. Victims of workplace violence have experienced feelings of fear and insecurity ${ }^{(10)}$, suggesting damage to workers' health.

In this sense, the results of this study show the association between the experience of violence and the prevalence of MPD, confirming other findings ${ }^{(9)}$. Regression analysis has highlighted that exposure to different forms of perpetrated violence is a high probability factor for developing MPD, confirming data from other studies about the negative influence of exposure to more types of violence on the mental health of workers ${ }^{(19,23)}$.

The association between violence at work and depression, anxiety and post-traumatic stress disorders has already been discussed ${ }^{(24)}$. In these conditions, feelings such as sadness, anger, shock, confusion and shame were associated with violence at work ${ }^{(5)}$.

A longitudinal study of 176 nurses from two American hospitals revealed the effects of exposure to physical violence on health in the form of somatic symptoms and musculoskeletal injury ${ }^{(25)}$. Another pointed out that the violence suffered by hospital workers can lead to increased use of psychotropic drugs, particularly antidepressants, but also anxiolytic ${ }^{(26)}$.

Regarding Burnout measured by the MBI, data from this study demonstrated that emotional exhaustion and depersonalization were higher for the victims of violence, therefore the dimensions of the scale were associated with workplace violence. Corroborating these data, a study of nurses from 11 public hospitals in Spain found that increased exposure to violence at work is associated with greater emotional exhaustion and depersonalization, and a lower level of psychological well-being ${ }^{(27)}$. Another Spanish study confirms the association of violence with the dimensions of emotional exhaustion and depersonalization ${ }^{(23)}$. Research conducted with nurses from 10 European coun- tries showed that the highest frequencies of violence were associated with higher levels of Burnout ${ }^{(12)}$, which was also concluded from a systematic review ${ }^{(5)}$.

\section{CONCLUSION}

Health workers experience violence in the workplace and this exposure is associated to symptoms of Burnout and MPD. Workers subjected to different forms of perpetrated violence experience these conditions even more.

The victims were predominantly women, younger workers, working more hours and having less education, and working as auxiliary/practical nurses. In addition to the Burnout symptoms and minor psychiatric disorders, the cruelties of violence proved to be linked to typical complications of labor, such as accidents and absenteeism, reflecting the complexity of the elements involved in the suffering and illness of workers. Exposure to violence also has a negative impact on job satisfaction and worker recognition.

These results have implications for the field of study and practice in occupational health, revealing the need for protective measures on the occurrence of violence and harm to the mental health of health care professionals, especially nursing. We must invest in monitoring systems for the incidents in order to identify measures that contain aggressors and to track the victims, thereby minimizing the damage of violence. This issue needs to have institutional guidelines, seeking to understand its origins and invest in a zero tolerance culture of violence at work.

Regarding the limitations of the study, the bias of reverse causality between the variables studied factor and outcomes should be considered. Given these speculations, we see the need for further studies, and recommend longitudinal designs seeking more evidence related to health and worker safety and the impact on patient care.

\section{RESUMO}

Objetivo: Identificar a violência sofrida pelos trabalhadores da equipe de saúde e a sua associação com burnout e transtornos psíquicos menores. Método: Estudo transversal, realizado com 269 profissionais da equipe de saúde em hospital público da região sul do Brasil. $\mathrm{Na}$ coleta de dados foram utilizados o Survey Questionnaire Workplace Violence in the Health Sector, Maslach Inventory Burnout e o SelfReport Questionaire. Resultados: A violência no trabalho acometeu 63,2\% dos trabalhadores, prevaleceu no sexo feminino ( $\mathrm{p}=0,001$ ), entre auxiliares/técnicos de enfermagem $(p=0,014)$ e foi associada aos transtornos psíquicos menores $(p<0,05)$, sendo que a exposição a diferentes formas de violência acresceu em 60\% as chances desses transtornos (IC95\%:1,2-2,1). As três dimensões do burnout também se associaram à violência no trabalho $(\mathrm{p}<0,05)$. Conclusão: Os trabalhadores de saúde sofrem violência em seu ambiente de trabalho e a essa exposição associam-se os sintomas de burnout e transtornos psíquicos menores.

\section{DESCRITORES}

Violência no Trabalho; Saúde do Trabalhador; Recursos Humanos em Saúde; Recursos Humanos de Enfermagem.

\section{RESUMEN}

Objetivo: Identificar la violencia sufrida por los trabajadores del equipo de salud y su asociación con burnout y trastornos psíquicos menores. Método: Estudio transversal, realizado con 269 profesionales del equipo de salud en hospital público de la región sur de Brasil. En la recolección de datos se utilizaron el Survey Questionnaire Workplace Violence in the Health Sector, el Maslach Inventory Burnout y el Self-Report Questionaire. Resultados: La violencia laboral comprometió al 63,2\% de los trabajadores, fue prevalente en el sexo femenino $(\mathrm{p}=0,001)$, entre auxiliares/técnicos de enfermería $(\mathrm{p}=0,014)$ y estuvo asociada con los trastornos psíquicos menores ( $\mathrm{p}<0,05)$, siendo que la exposición a distintas formas de violencia añadió en el 60\% la probabilidad de ocurrir dichos trastornos (IC95\%:1,2-2,1). Las tres dimensiones del burnout también se asociaron con la violencia laboral $(p<0,05)$. Conclusión: Los trabajadores de salud sufren violencia en su ambiente laboral y con esa exposición se asocian los síntomas de burnout y trastornos psíquicos menores.

\section{DESCRIPTORES}

Violencia Laboral; Salud Laboral; Recursos Humanos en Salud; Personal de Enfermería. 


\section{REFERENCES}

1. Organización Internacional del Trabajo; Consejo Internacional de Enfermeras; Organización Mundial de la Salud; Internacional de Servicios Públicos. Directrices marco para afrontar la violencia laboral en el Sector de la Salud [Internet] Ginebra: OIT; 2002 [citado 2014 jun. 27]. Disponíbel en: http://www.ilo.org/wcmsp5/groups/public/---ed_dialogue/---sector/documents/publication/wcms_160911.pdf

2. Spector PE, Zhou ZE, Che XX. Nurse exposure to physical and nonphysical violence, bullying, and sexual harassment: a quantitative review. Int J Nurs Stud. 2014;51(1):72-84.

3. Campos AC, Pierantoni CR. Violência no trabalho em saúde: um tema para a cooperação internacional em recursos humanos para a saúde. R Eletr Com Inf Inov Saúde. 2010;4(1):86-92.

4. Farrell GA, Shafiei T. Workplace aggression, including bullying in nursing and midwifery: a descriptive survey: the SWAB study. Int J Nurs Stud. 2012;49(11):1423-31.

5. Edward KL, Ousey K, Warelow P, Lui S. Nursing and aggression in the workplace: a systematic review. Br J Nurs. 2014;23(12):653-4.

6. Hahn S, Hantikainen V, Needham I, Kok G, Dassen T, Halfens RJG. Patient and visitor violence in the general hospital, occurrence, staff interventions and consequences: a cross-sectional survey. J Adv Nurs. 2012;68(12):2685-99.

7. Dal Pai D, Lautert L. Work under urgency and emergency and its relation with the health of nursing professionals. Rev Latino Am Enfermagem. 2008;16(3):439-44.

8. Vasconcellos IRR, Abreu AMM, Maia EL. Violência ocupacional sofrida pelos profissionais de enfermagem do serviço de pronto atendimento hospitalar. Rev Gaúcha Enferm. 2012;33(2):167-75.

9. Vasconcellos IRR, Griep RH, Lisboa MTL, Rotenberg L. Violence in daily hospital nursing work. Acta Paul Enferm. 2012;25(n.spe2):40-7.

10. Batista CB, Campos AS, Reis JC, Schall VT. Violência no trabalho em saúde: análise em unidades básicas de saúde de Belo Horizonte, Minas Gerais. Trab Educ Saúde. 2011;9(2):295-317.

11. Santos AMR, Soares JCN, Nogueira LF, Araújo NA, Mesquita GV, Leal CFS. Violência institucional: vivências no cotidiano da equipe de enfermagem. Rev Bras Enferm. 2011;64(1):84-90.

12. Estryn-Behar M, Heijden B, Camerino D, Fry C, Nezet OL, Conway PM, Hasselhorn HM. Violence risks in nursing: esults from the European 'NEXT' Study. Occup Med. 2008;58(2):107-14.

13. Lautert L. O desgaste profissional: estudo empírico com enfermeiras que trabalham em hospitais. Rev Gaúcha Enferm. 1997;18(2):133-44.

14. 14 Mari JJ, Williams P. A validity study of a psychiatric screening questionnaire (SRQ-20) in primary care in the city of São Paulo. Br J Psychiatry [Internet]. 1986 [cited 2014 July 12];148:23-6. Available from: http://bjp.rcpsych.org/content/bjprcpsych/148/1/23.full.pdf

15. Di Martino V. Workplace violence in the health sector - country case studies: Brazil, Bulgarian, Lebanon, Portugal, South Africa, Thailand, plus an additional Australian study: synthesis report [Internet]. Geneva: WHO; 2003 [cited 2014 Oct 22]. Available from: http://www.who. int/violence_injury_prevention/injury/en/WVsynthesisreport.pdf

16. Palácios M. Relatório Preliminar de Pesquisa. Violência no trabalho no Setor Saúde - Rio de Janeiro - Brasil [Internet]. Rio de Janeiro: Universidade Federal do Rio de Janeiro; 2002 [citado 2014 set. 03]. Disponível em: http://www.assediomoral.org/IMG/pdf/pesquisa_sobre_Violencia_no_trabalho_Universidade_Federal_RJ.pdf

17. Maslach C, Jackson S. The measurement of experienced Burnout. J Occup Behav. 1981;2(1):99-113.

18. Silva IV, Aquino EML, Pinto ICM. Violência no trabalho em saúde: a experiência de servidores estaduais da saúde no Estado da Bahia, Brasil. Cad Saúde Pública. 2014;30(10):2112-22.

19. Cavanaugh C, Campbell J, Messing JT. A longitudinal study of the impact of cumulative violence victimization on comorbid posttraumatic stress and depression among female nurses and nursing personnel. Workplace Health Saf. 2014;62(6):224-32.

20. Gillespie GL, Gates DM, Miller M, Howard PH. Workplace violence in healthcare settings: risk factors and protective strategies. Rehabil Nurs. 2010;35(5):177-84

21. Pai HC, Lee S. Risk factors for workplace violence in clinical registered nurses in Taiwan. J Clin Nurs. 2011;20(9-10):1405-12.

22. Roche M, Diers D, Duffield C, Catling-Paull C. Violence toward nurses, the work environment, and patient outcomes. J Nurs Scholarsh. 2010;42(1):13-22.

23. Bernaldo-De-Quirós M, Piccini AT, Gómez MM, Cerdeira JC. Psychological consequences of aggression in pre-hospital emergency care: cross sectional survey. Int J Nurs Stud. 2015;52(1):260-70.

24. Gates DM, Gillespie GL, Succop P. Violence against nurses and its impact on stress and productivity. Nurs Econ. 2011;29(2):59-66.

25. Yang LQ, Spector PE, Chang CH, Gallant-Roman M, Powell J. Psychosocial precursors and physical consequences of workplace violence towards nurses: a longitudinal examination with naturally occurring groups in hospital settings. Int J Nurs Stud. 2012;49(9):1091-102.

26. Dement JM, Lipscomb HJ, Schoenfisch AL, Pompeii LA. Impact of hospital type II violent events: use of psychotropic drugs and mental health services. Am J Ind Med. 2014;57(6):627-39.

27. Waschgler K, Ruiz-Hernández JA, Llor-Esteban B, García-Izquierdo M. Patients' aggressive behaviours towards nurses: development and psychometric properties of the hospital aggressive behaviour scale-users. J Adv Nurs. 2013;69(6):1418-27. 